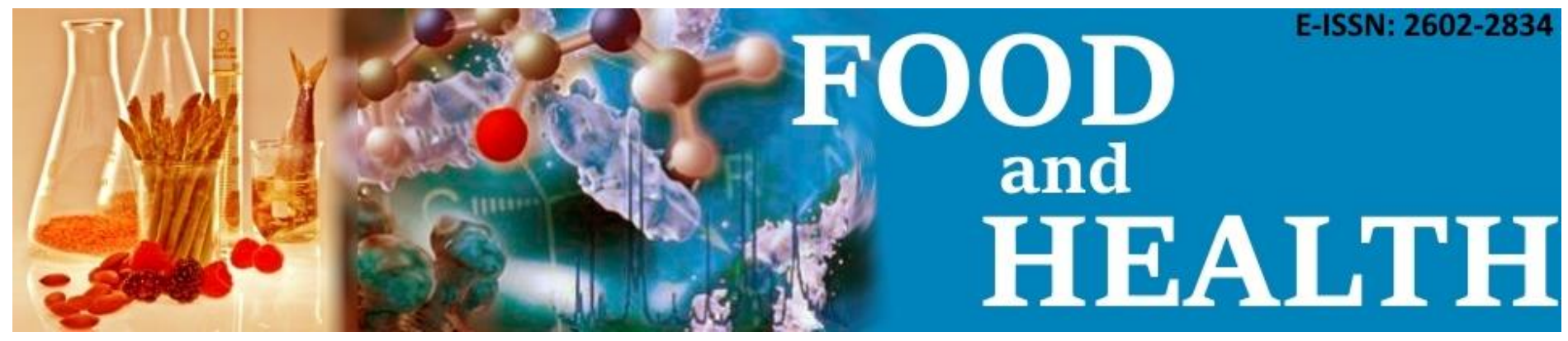

\title{
CHEMOMETRIC EVALUATION OF THE GEOGRAPHICAL ORIGIN OF TURKISH PINE HONEY
}

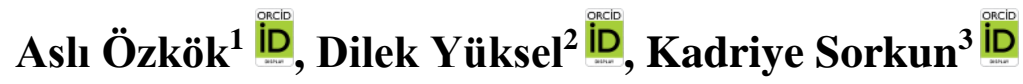

\section{Cite this article as:}

Özkök, A., Yüksel, D., Sorkun, K. (2018). Chemometric Evaluation of the Geographical Origin of Turkish Pine Honey. Food and Health, 4(4), $274-282$. DOI: $10.3153 / \mathrm{FH} 18027$

\footnotetext{
${ }^{1}$ Hacettepe University, Bee and Bee Products Application and Research Center, 06800, Beytepe, Ankara, Turkey

${ }^{2}$ Hacettepe University, Faculty of Sciences, Department of Chemistry, 06800, Beytepe, Ankara, Turkey

${ }^{3}$ Hacettepe University, Faculty of Sciences, Department of Biology, 06800, Beytepe, Ankara, Turkey
}

Submitted: 28.12 .2017

Accepted: 26.02.2018

Published online: 01.06.2018

Correspondence:

Aslı ÖZKÖK

E-mail: aozkok@hacettepe.edu.tr

\begin{abstract}
The aim of the study was to characterize Turkish pine honey samples and classify them according to their geographical origin. Marchalina hellenica, which lives on Pinus brutia, is the main source of pine honey in Turkey. The honeybee (Apis mellifera) collects honeydew for making pine honey.In this study, 26 pine honey samples from five different districts of Muğla were classified as high quality pine honey via melissopalynological analysis and subjected to chemical analysis to evaluate physicochemical parameters. To classify honey samples according to their geographical origin, multivariate analysis of variance (MANOVA) and linear discriminant analysis (LDA) were performed on the experimental data. By using 13 variables (three microscopic quantities, seven physicochemical parameters, and three selected volatile compounds) as predictors for LDA, all honey samples were correctly classified according to their geographical origin. To the best of our knowledge, there is no information in the literature on the classification of Turkish pine honey according to geographical origin; thus, the outcomes of this study are important for the characterization, classification, and authenticity of Turkish pine honey. In addition, these results can used the comparison and standardization of honeydew honey varieties in the world.
\end{abstract}

Keywords: Chemical parameters, Marchalina hellenica, Melissopalynology, Multivariate analysis, Pine honey 


\section{Introduction}

Honey is a natural food, and its quality and composition are important for healthy human consumption. Honey can be broadly categorized as floral or honeydew honey. Floral honey is derived from honeybees collecting nectar from plants, whereas honeydew honey is derived from honeybees collecting sweet substances mainly from the excretions of plant-sucking insects (Hemiptera) on the living parts of plants or secretions of the living parts of plants (Sanz et al., 2005; Karabagias et al., 2014). Clover, thyme, acacia, and citrus are some examples of floral honey varieties, while pine and fir are examples of honeydew honey varieties.

The majority of the world's pine honey (about 90\%) is produced in the Muğla region of Turkey because of the suitable climatic conditions and relative humidity for Marchalina hellenica (syn. Monophlebus hellenicus) (Coccoidea: Homoptera) and its natural host, Pinus brutia. M. hellenica is a type of insect that lives on P. brutia and is the main source of honeydew. This insect is found only in Turkey and Greece (Santas, 1979). In Turkey, about $30 \%$ of all honey is produced in the region of Muğla as the region has nearly 60,000 ha of Pinus brutia forest (Şahin, 2000). Turkey produces an estimated 90,000 tons of honey annually (FAOSTAT, 2014) and 25,000 to 30,000 tons of this is pine honey. Most of the pine honey is exported all over the world (Maybir, 2015). Therefore, the quality and authenticity of pine honey is as important as floral honey. Microscopic analysis and chemical analysis show the honey quality and authenticity. Honeydew honey is generally characterized by honeydew elements composed of microscopic algae, fungus spores. If a honey with the ratio "number of honeydew elements (HDE)"/ "number of total pollens $(\mathrm{P})$ " is greater than 3, is considered as honeydew honey (Louveaux et al., 1978; Soria et al., 2004). If the HDE/P is 4.5, is called high density superior quality honeydew honey (Sorkun, 2008).

Moisture, 5-hydroxymethylfurfuraldehyde (HMF), free acidity (FA), lactonic acidity (LA), total acidity (TA), and $\mathrm{pH}$ analyses are some of the important criteria for evaluating honey. Among them, HMF is an indication of the quality of honey. HMF is produced from sugars by the decomposition of monosaccharides (Leshkov et al., 2006; Simeonov et al., 2016) when honey is heated or stored for a long time the concentration of HMF significantly increases (Silva et al., 2016).

Moisture is another important factor that determines honey quality as it is the second largest constituent of honey. Moisture affects the physical properties of honey, such as viscosity and crystallization, as well as other parameters such as color, flavor, taste, specific gravity, solubility, and conservation (Escuredo et al., 2013; Silva et al., 2016).

FA, LA, TA, and $\mathrm{pH}$ are the other parameters that determine the authenticity of honey. According to White (1975), the $\mathrm{pH}$ of honey should be between 3.2 and 4.5. Honey contains between $0.17-1.17 \%$ organic acids and between 0.05$0.15 \%$ amino acids (D'Arcy, 2007). They are responsible for the characteristic taste and acidity of honey (Krell, 1996). The natural acidity of honey inhibits the growth of microorganisms, as the optimum $\mathrm{pH}$ for most organisms is between 7.2-7.4 (Karabagias et al., 2014; Silva et al., 2016).

FA is related to the deterioration of honey. It is characterized by the presence of organic acids in equilibrium with lactone, internal esters, and some inorganic ions such as phosphates, sulfates, and chlorides (Moreira et al., 2010). Electrical conductivity (EC) depends upon the mineral content, organic acids, proteins, and other substances in honey (D'Arcy, 2007). Conductivity is a useful criterion to determine the botanic origin of honey and thus is frequently used in routine analyses (Bogdanov, 2002). The EC value of floral honey is lower than that of honeydew honey (Bogdanov, 1999). Honey contains at least four broad groups of components that have antioxidant activity, polyphenols or phenolic compounds (flavonoids and phenolic acids), enzymes (e.g. glucose oxidase and catalase), ascorbic acid, and peptides (Nicholls \& Miraglio, 2003). Volatile compounds are also important for honey quality, and they vary according to botanical origin (Karabagias et al., 2014).

In this study, we experimentally determined microscopic quantities such as the number of honeydew elements (HDE), the number of total pollen $(\mathrm{P})$, and HDE/P. In addition, the HMF, moisture, FA, LA, TA, pH, and volatile contents of pine honey samples were analyzed. Besides the analytical results from the present study, EC (Özkök \& Çıng1, 2010) and volatile compounds (Özkök et al., 2016) values from our previous studies were also used for statistical analyses. To the best of our knowledge, there is no information in the literature on the classification of Turkish pine honey according to geographical origin; thus, the outcomes of this study are important for the characterization, classification, and authenticity of Turkish pine honey.

\section{Materials and Methods}

\section{Collection of Honey Samples}

Honey samples were collected from five areas (Milas, Ortaca, Marmaris, Fethiye, and Datça) around Muğla city 
where pine honey beekeeping is extensively practiced. Suitable apiaries were chosen according to vegetation diversity and distance between the villages. Samples were stored in glass containers, shipped to the laboratory, and maintained at $4^{\circ} \mathrm{C}$ until analysis.

\section{Melissopalynological Analysis (Microscopic Analysis)}

Analytes for the identification of P and HDE in $10 \mathrm{~g}$ of honey were obtained according to procedure of Louveaux et al., 1978 and Sorkun, 2008.

$10 \mathrm{~g}$ honey was mixed with $20 \mathrm{~mL}$ of distilled water in a tube together with a tablet containing 12542 Lycopodium spores. To dissolve the tablet, tubes were incubated for 10$15 \mathrm{~min}$ in a water bath at $45^{\circ} \mathrm{C}$. After the tablet was fully dissolved, few drops of basic fuchsine were added to stain the pollens and spores, and the mixture was centrifuged at $3500 \mathrm{rpm}$ for $45 \mathrm{~min}$. Water from the centrifuged tubes was removed, and the tubes were dried upside down on a drying mat to fully drain the fluid. Then, $1 \mathrm{~mL}$ of $50 \%$ glycerine was added to the precipitate of each tube and mixed homogenously. Subsequently, $0.01 \mathrm{~mL}$ was withdrawn from this mixture and plated on a lamella. The material was covered by a lamella $\left(18 \times 18 \mathrm{~mm}^{2}\right)$, and two separate analytes were obtained for microscopic analysis.

\section{Examination of the Number of Total Pollen $(P)$}

Pollen and spore analytes were examined and counted under a Nicon Eclipse E400 light microscope at $20 \times$ and $40 \times$ magnification. During the counting process, analytes were examined starting from the top left corner to eventually cover the whole area $\left(18 \times 18 \mathrm{~mm}^{2}\right)$; the numbers of pollens and Lycopodium spores in this area were counted separately. Counts of two separate analytes were obtained, and their averages were applied to the formula below:

$$
\begin{aligned}
& \text { Number of total pollen } \frac{\mathrm{P}}{10} \mathrm{~g} \\
& \qquad=\frac{\text { Pollens counted } \times 12542 *}{\text { Lycopodium spores counted }}
\end{aligned}
$$

*Number of spores found in one Lycopodium tablet

Examination of the Number of Honeydew Elements (HDE)

In the same analytes in which $\mathrm{P}$ was counted, HDE was also counted. During this process, starting from the top left corner to eventually cover the whole area $\left(18 \times 18 \mathrm{~mm}^{2}\right)$, the numbers of spores, hyphea, and any algae present were counted. The HDE content in $10 \mathrm{~g}$ of honey was determined by the following formula:

Number of honeydew elements (HDE)/10 g

$=\frac{\text { Number }(\text { spore }+ \text { hyphea }+ \text { algae }) \text { counted } \times 12542}{\text { Lycopodium spores counted }}$

\section{HDE/P Ratio}

Based on the results of microscopic identification, all honey samples were identified as high density-superior quality pine honey and thus appropriate for chemical analysis.

\section{HMF Analysis}

Bogdanov (2002)'s HMF method was followed for the HMF analyses. Initially, $5 \mathrm{~g}$ of honey was dissolved in $25 \mathrm{~mL}$ water and transferred to a $50 \mathrm{~mL}$ volumetric flask. Then, 0.5 $\mathrm{mL}$ of Carrez solution I ( $15 \mathrm{~g}$ of potassium hexacyanoferrate dissolved in water and made up to $100 \mathrm{~mL}$ ) was added, and the solution was mixed. Subsequently, $0.5 \mathrm{~mL}$ of Carrez solution II ( $30 \mathrm{~g}$ of zinc acetate made up to $100 \mathrm{~mL}$ with water) was added, mixed, and made up to the mark with water. The mixture was filtered through paper, rejecting the first $10 \mathrm{~mL}$ filtrate. Then, $5.0 \mathrm{~mL}$ of the resulting filtrate was pipetted into each of two test tubes; $5.0 \mathrm{~mL}$ of $0.2 \%$ sodium bisulfite solution was added to the second test tube and mixed well. The absorbance of the sample solution was determined against the reference solution at 284 and $336 \mathrm{~nm}$ in $10 \mathrm{~mm}$ quartz cells within $1 \mathrm{~h}$. HMF values were calculated according to the following formula:

$$
\text { HMF mg } / \mathrm{kg}=\frac{(\text { Absorbance284 }- \text { Absorbance336) } \times 149.7 \times 5 \times \text { Dilution factor }(\mathrm{D})}{\text { Weight }(\mathrm{W})}
$$




\section{Moisture Analysis}

Moisture analysis was performed according to a refractometric method. The homogenate of $1 \mathrm{~g}$ pine honey sample was measured by a refractometer. Each sample was measured twice, and the average value was determined.

\section{FA, LA, TA, and pH Analysis}

FA, LA, TA, and $\mathrm{pH}$ analyses were performed according to a procedure described by Bogdanov (2002). Initially, $5 \mathrm{~g}$ of pine honey was dissolved in a few milliliters of water. The solution was then transferred quantitatively to a $50 \mathrm{~mL}$ volumetric flask and filled to the mark with water. After mixing well, $25 \mathrm{~mL}$ of the solution was pipetted into a $250 \mathrm{~mL}$ beaker. A bar magnet was added, and the initial $\mathrm{pH}$ (pHi) was noted. The solution was stirred gently and titrated first with sodium hydroxide solution (up to $10 \mathrm{~mL}$ ), then (into the same beaker) with sulfuric acid solution (up to the second equivalence point). The results were calculated according to formula.

FA is expressed in milliequivalents of sodium hydroxide required to neutralize $1 \mathrm{~kg}$ of honey.

$\mathrm{FA}=\mathrm{V} \times \mathrm{T} \times(50 / 25) \times(1000 / \mathrm{M})$

LA is expressed in the same units:

$$
\mathrm{LA}=\left[(10-\mathrm{V}) \times \mathrm{T}-0.05 \times \mathrm{V}^{\prime}\right] \times(50 / 25) \times(1000 / \mathrm{M})
$$

TA is expressed in the same units:

$$
\mathrm{TA}=\mathrm{FA}+\mathrm{LA}
$$

\section{Chemometric Methods}

Multivariate statistical analysis of the experimental data was conducted using SPSS statistical software version 23.0 (SPSS Inc., Chicago, IL, USA). Discriminant analysis was performed using multivariate analysis of variance (MANOVA) followed by linear discriminant analysis (LDA). All data were scaled with Fischer's method, and all models were cross-validated using the leave-one-out method. A $26 \times 13$ data matrix, corresponding to 26 pine honey samples and 13 experimental variables (HDE, P, HDE/P, moisture, pH, FA, LA, LA/FA, EC, HMF, eicosane, 2 -furanmethanol, and lidocaine contents) were used to predict the geographical origin of honey samples.

\section{Results and Discussion}

Microscopic, physicochemical parameters, volatile compounds analysis results of 26 honey samples showed Figure 1, Table 1, 2 and 3.

For the geographical classification of 26 pine honey samples from five different districts (five samples from Datça, five samples from Fethiye, six samples from Marmaris, seven samples from Milas, and three samples from Ortaca), 13 experimentally determined quantities (HDE, P, HDE/P, moisture, $\mathrm{pH}, \mathrm{FA}, \mathrm{LA}, \mathrm{LA} / \mathrm{FA}, \mathrm{EC}, \mathrm{HMF}$, eicosane, 2-furanmethanol, and lidocaine) were used as predictors for multivariate statistical analysis. All of the 13 predictors were subjected to MANOVA to elucidate the effect of geographical origin on the microscopic and chemical properties of pine honey samples.

According to Codex Alimentarius Committee on Sugars (2001) a maximum value of HMF for mixed or processed honey $40 \mathrm{mg} / \mathrm{kg}$ and a maximum value of HMF if the honey and blends of honey originate from regions with a tropical climate $80 \mathrm{mg} / \mathrm{kg}$. In this study, the HMF analysis results of 26 samples revealed a minimum of $0.14 \mathrm{mg} / \mathrm{kg}$, a maximum of $44.54 \mathrm{mg} / \mathrm{kg}$, and an average of $4.93 \mathrm{mg} / \mathrm{kg}$. Unsuitable samples could indicate overheating or inadequate storage conditions.

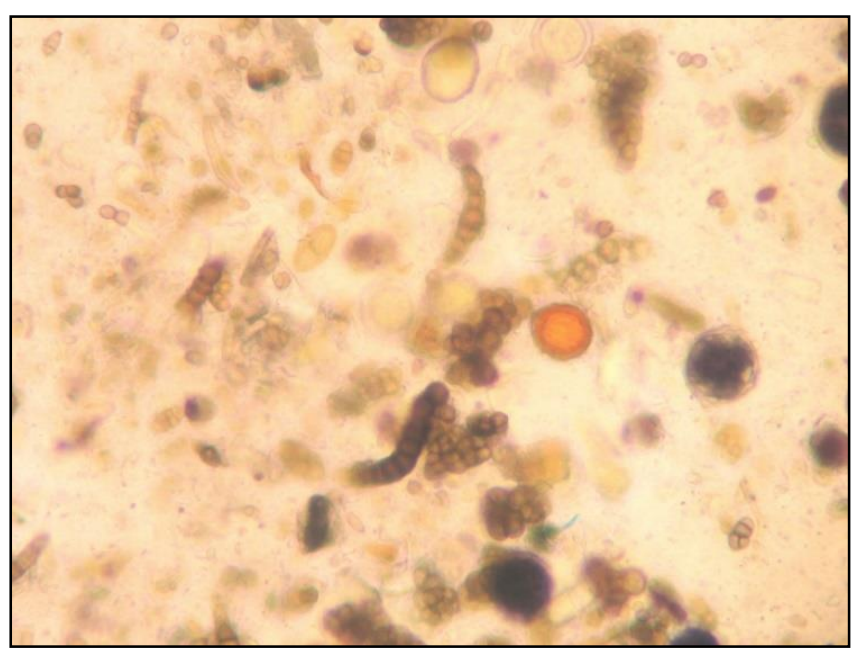

Figure 1. Turkish Pine honey 
Table 1. Outcomes of HDE/P analysis of honey samples

\begin{tabular}{|c|c|c|c|c|c|}
\hline Sample No & District & HDE & $\mathbf{P}$ & HDE/P & Identification \\
\hline 1 & Datça & 59408 & 9995 & 5.94 & High density superior quality pine honey \\
\hline 2 & Datça & 55770 & 10940 & 5.09 & High density superior quality pine honey \\
\hline 3 & Datça & 66041 & 10778 & 6.12 & High density superior quality pine honey \\
\hline 4 & Datça & 77949 & 5124 & 15.2 & High density superior quality pine honey \\
\hline 5 & Datça & 92446 & 9507 & 9.7 & High density superior quality pine honey \\
\hline 6 & Fethiye & 498544 & 4703 & 106 & High density superior quality pine honey \\
\hline 7 & Fethiye & 146542 & 8449 & 17.3 & High density superior quality pine honey \\
\hline 8 & Fethiye & 89884 & 10451 & 8.6 & High density superior quality pine honey \\
\hline 9 & Fethiye & 116040 & 5889 & 19 & High density superior quality pine honey \\
\hline 10 & Fethiye & 192481 & 23292 & 8.26 & High density superior quality pine honey \\
\hline 11 & Marmaris & 166366 & 9222 & 18.04 & High density superior quality pine honey \\
\hline 12 & Marmaris & 189892 & 11758 & 16.15 & High density superior quality pine honey \\
\hline 13 & Marmaris & 66284 & 12736 & 5.2 & High density superior quality pine honey \\
\hline 14 & Marmaris & 118880 & 26391 & 4.5 & High density superior quality pine honey \\
\hline 15 & Marmaris & 168200 & 28623 & 5.87 & High density superior quality pine honey \\
\hline 16 & Marmaris & 128168 & 12370 & 10.36 & High density superior quality pine honey \\
\hline 17 & Milas & 75542 & 16802 & 4.5 & High density superior quality pine honey \\
\hline 18 & Milas & 213810 & 2388 & 89.53 & High density superior quality pine honey \\
\hline 19 & Milas & 67215 & 731 & 92 & High density superior quality pine honey \\
\hline 20 & Milas & 110731 & 7231 & 15.3 & High density superior quality pine honey \\
\hline 21 & Milas & 135453 & 5495 & 24.6 & High density superior quality pine honey \\
\hline 22 & Milas & 214864 & 9241 & 23.2 & High density superior quality pine honey \\
\hline 23 & Milas & 167851 & 5860 & 28.6 & High density superior quality pine honey \\
\hline 24 & Ortaca & 55944 & 1832 & 30.5 & High density superior quality pine honey \\
\hline 25 & Ortaca & 123341 & 12888 & 9.5 & High density superior quality pine honey \\
\hline 26 & Ortaca & 121619 & 5320 & 22.8 & High density superior quality pine honey \\
\hline
\end{tabular}

Table 2. Physicochemical parameters for pine honey samples

\begin{tabular}{|c|c|c|c|c|c|c|c|c|}
\hline $\begin{array}{c}\text { Sample } \\
\text { No }\end{array}$ & $\begin{array}{c}\begin{array}{c}\text { Moisture } \\
(\mathrm{g} / \mathbf{1 0 0 g})\end{array} \\
\end{array}$ & pH & $\begin{array}{c}\text { FA } \\
(\mathrm{meq} / \mathrm{kg})\end{array}$ & $\begin{array}{c}\mathbf{L A} \\
(\mathrm{meq} / \mathrm{kg})\end{array}$ & $\begin{array}{c}\text { TA } \\
(\mathrm{meq} / \mathrm{kg})\end{array}$ & LA/FA & $\begin{array}{c}\text { HMF } \\
(\mathrm{mg} / \mathrm{kg})\end{array}$ & $\begin{array}{c}\mathbf{E C}^{*} \\
\mathrm{mS} / \mathrm{cm}\end{array}$ \\
\hline 1 & 15.2 & 4.81 & 7.36 & 15.60 & 22.96 & 2.12 & 2.00 & 1.49 \\
\hline 2 & 15.5 & 4.67 & 11.04 & 15.60 & 26.64 & 1.41 & 1.47 & 1.52 \\
\hline 3 & 17.2 & 5.11 & 9.20 & 15.60 & 24.80 & 1.70 & 0.42 & 1.24 \\
\hline 4 & 15.5 & 5.19 & 9.20 & 15.60 & 24.80 & 1.70 & 0.95 & 1.42 \\
\hline 5 & 17.5 & 5.24 & 9.20 & 10.40 & 19.60 & 1.13 & 2.53 & 1.51 \\
\hline 6 & 14.0 & 4.22 & 14.72 & 15.60 & 30.32 & 1.06 & 15.26 & 0.89 \\
\hline 7 & 14.2 & 4.74 & 14.72 & 20.80 & 35.52 & 1.41 & 1.35 & 1.31 \\
\hline 8 & 14.6 & 5.17 & 9.20 & 18.20 & 27.40 & 1.98 & 0.57 & 1.19 \\
\hline 9 & 17.0 & 6.32 & 18.40 & 13.00 & 31.40 & 0.71 & 0.50 & 1.21 \\
\hline 10 & 21.5 & 4.40 & 18.40 & 18.20 & 36.60 & 0.99 & 1.70 & 1.06 \\
\hline 11 & 17.0 & 4.17 & 20.24 & 26.00 & 46.24 & 1.28 & 12.61 & 1.83 \\
\hline 12 & 18.4 & 3.98 & 20.24 & 20.80 & 41.04 & 1.03 & 8.26 & 1.71 \\
\hline 13 & 16.5 & 4.18 & 12.88 & 18.20 & 31.08 & 1.41 & 44.54 & 1.15 \\
\hline 14 & 18.4 & 4.26 & 20.24 & 20.80 & 41.04 & 1.03 & 5.56 & 1.66 \\
\hline 15 & 14.0 & 4.33 & 20.24 & 20.80 & 41.04 & 1.03 & 3.67 & 1.51 \\
\hline 16 & 15.2 & 4.56 & 20.24 & 20.80 & 41.04 & 1.03 & 7.17 & 1.42 \\
\hline 17 & 15.5 & 4.83 & 12.88 & 18.20 & 31.08 & 1.41 & 2.80 & 0.94 \\
\hline 18 & 15.0 & 4.98 & 12.88 & 18.20 & 31.08 & 1.41 & 2.40 & 1.46 \\
\hline 19 & 15.0 & 4.92 & 9.20 & 18.20 & 27.40 & 1.98 & 1.57 & 1.38 \\
\hline 20 & 15.8 & 5.08 & 11.04 & 18.20 & 29.24 & 1.65 & 2.57 & 1.27 \\
\hline 21 & 15.0 & 5.26 & 7.36 & 15.60 & 22.96 & 2.12 & 0.14 & 1.22 \\
\hline 22 & 16.2 & 4.61 & 9.20 & 18.20 & 27.40 & 1.98 & 2.14 & 1.09 \\
\hline 23 & 16.2 & 4.59 & 11.04 & 18.20 & 29.24 & 1.65 & 1.25 & 1.17 \\
\hline 24 & 12.0 & 4.52 & 16.56 & 20.80 & 37.36 & 1.26 & 1.70 & 1.61 \\
\hline 25 & 15.2 & 5.31 & 14.72 & 20.80 & 35.52 & 1.41 & 2.07 & 2.19 \\
\hline 26 & 17.0 & 5.22 & 9.20 & 15.60 & 24.80 & 1.70 & 3.00 & 2.26 \\
\hline Average & 16.0 & 4.80 & 13.45 & 18.00 & 31.45 & 1.45 & 4.93 & 1.41 \\
\hline Min. & 12.0 & 3.98 & 7.36 & 10.40 & 19.60 & 0.71 & 0.14 & 0.89 \\
\hline Max. & 21.5 & 6.32 & 20.24 & 26.00 & 46.24 & 2.12 & 44.54 & 2.26 \\
\hline
\end{tabular}

${ }^{*}$ Data is taken from Özkök \& Çıngı, (2010). 
Table 3. Volatile compounds found in pine honey samples (\% content)*

\begin{tabular}{|c|c|c|c|c|c|c|c|c|c|c|c|c|}
\hline & \multicolumn{2}{|c|}{ Aldehydes } & \multirow{2}{*}{ 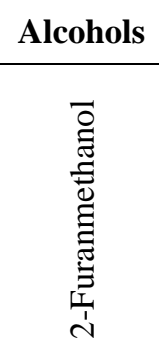 } & \multirow{2}{*}{ 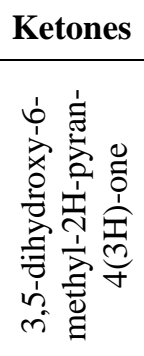 } & \multicolumn{4}{|c|}{ Hydrocarbons } & \multicolumn{2}{|c|}{ Acids } & \multirow{2}{*}{ 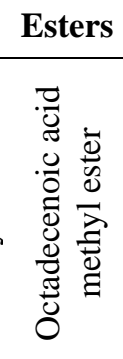 } & \multirow{2}{*}{ 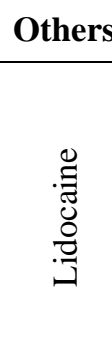 } \\
\hline 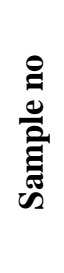 & 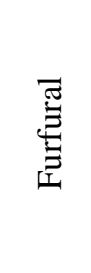 & 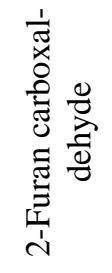 & & & 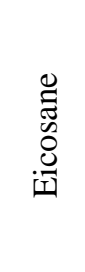 & 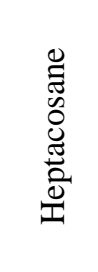 & 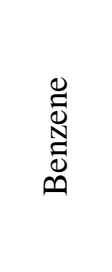 & 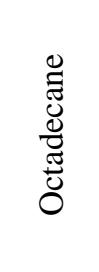 & 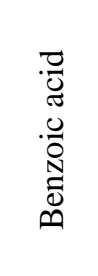 & 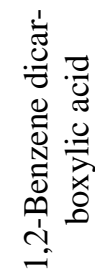 & & \\
\hline 1 & nd & nd & nd & nd & 1.02 & nd & 28.94 & nd & nd & nd & 1.78 & 5.64 \\
\hline 2 & nd & nd & nd & nd & nd & nd & nd & nd & nd & nd & nd & 3.74 \\
\hline 3 & nd & nd & 1.46 & 2.41 & 1.44 & nd & nd & nd & nd & nd & nd & 2.43 \\
\hline 4 & nd & nd & 1.64 & 2.57 & nd & 1.19 & nd & nd & 1.26 & nd & nd & 4.67 \\
\hline 5 & nd & nd & 1.35 & 2.26 & nd & nd & nd & nd & nd & nd & 0.52 & 3.46 \\
\hline 6 & nd & nd & 1.92 & nd & nd & nd & nd & nd & nd & nd & nd & 0.95 \\
\hline 7 & nd & nd & nd & nd & 0.46 & nd & nd & nd & nd & 1.81 & nd & 2.01 \\
\hline 8 & nd & nd & nd & nd & nd & nd & 0.75 & nd & nd & nd & nd & 0.98 \\
\hline 9 & nd & nd & 1.33 & 2.77 & 0.38 & nd & 4.86 & nd & nd & nd & 0.44 & 2.50 \\
\hline 10 & 1.33 & nd & 0.57 & 1.98 & nd & nd & nd & nd & nd & nd & nd & 2.09 \\
\hline 11 & nd & nd & 0.96 & 1.38 & 0.33 & nd & nd & 0.44 & nd & nd & nd & 2.41 \\
\hline 12 & nd & nd & nd & nd & nd & nd & 27.67 & nd & nd & nd & nd & 1.02 \\
\hline 13 & nd & nd & 1.91 & 2.33 & 0.11 & 0.14 & nd & nd & nd & nd & nd & 3.21 \\
\hline 14 & nd & nd & nd & nd & nd & nd & nd & nd & nd & nd & nd & 3.59 \\
\hline 15 & nd & nd & 1.14 & 1.50 & nd & nd & nd & nd & nd & nd & nd & 5.19 \\
\hline 16 & 0.35 & nd & 1.30 & 2.43 & 0.29 & 0.36 & nd & nd & 2.28 & nd & nd & 3.90 \\
\hline 17 & nd & nd & 0.93 & nd & 3.3 & nd & nd & nd & nd & nd & nd & 2.82 \\
\hline 18 & 0.49 & nd & 1.10 & 2.14 & nd & nd & nd & nd & nd & nd & nd & 2.27 \\
\hline 19 & nd & nd & 1.20 & 2.01 & nd & nd & nd & nd & 0.64 & nd & nd & 3.10 \\
\hline 20 & nd & 13.05 & 1.29 & 3.31 & 1.43 & nd & nd & nd & nd & nd & 0.36 & 1.55 \\
\hline 21 & nd & nd & 1.57 & nd & 0.70 & 0.94 & nd & nd & nd & nd & nd & 2.04 \\
\hline 22 & nd & nd & 1.02 & nd & 1.36 & nd & nd & nd & nd & nd & nd & 2.19 \\
\hline 23 & nd & nd & 1.15 & nd & 0.37 & 1.30 & 13.53 & nd & nd & nd & nd & 1.78 \\
\hline 24 & nd & nd & nd & nd & 1.79 & 1.89 & nd & nd & 1.86 & nd & nd & 7.53 \\
\hline 25 & nd & nd & 1.40 & 2.47 & 1.07 & nd & nd & nd & 1.47 & nd & nd & 8.86 \\
\hline 26 & 0.51 & 5.80 & 1.78 & 2.01 & nd & nd & nd & nd & nd & nd & nd & 2.91 \\
\hline
\end{tabular}

nd not determined

* Data is taken from Özkök, Sorkun, \& Salih, (2016).

The average $\mathrm{pH}$ of honey is 3.9 , but it is higher generally for honeydew honey (White \& Doner, 1980). The $\mathrm{pH}$ analysis results of our honeydew honey samples revealed an average 4.80, a minimum of 3.98, and a maximum of 6.32. Escuredo, Fernandez-Gonzalez \& Carmen (2012) reported pH values of between 3.5 and 5.0 for honey samples from Northwest Spain. Similarly, Karabagias et al., (2014) found $\mathrm{pH}$ values of between 4.42 and 5.20 for Greek pine honey samples.

In the present study, FA ranged from $7.36 \mathrm{meq} / \mathrm{kg}$ to 20.24 $\mathrm{meq} / \mathrm{kg}$. FA values should be lower than $50 \mathrm{meq} / \mathrm{kg}$ according to the Council Directive 2001/110/EC. All samples (100\% of the samples) in our study meet these standards. Higher values could indicate the fermentation of sugars into organic acids. On the other hand according to Silva et al.,
(2016) the presence of different organic acids, geographical origin, and harvest season can affect honey acidity. LA results revealed an average of $18.00 \mathrm{meq} / \mathrm{kg}$, a minimum of $10.4 \mathrm{meq} / \mathrm{kg}$, and a maximum of $26 \mathrm{meq} / \mathrm{kg}$. TA results revealed an average of $30.81 \mathrm{meq} / \mathrm{kg}$, a minimum of 14.84 $\mathrm{meq} / \mathrm{kg}$, and a maximum of $46.24 \mathrm{meq} / \mathrm{kg}$. Karabagias et al., (2014) found that FA ranged between $18.08 \mathrm{meq} / \mathrm{kg}$ and $41.54 \mathrm{meq} / \mathrm{kg}$, LA ranged between $1.59 \mathrm{meq} / \mathrm{kg}$ and 5.59 , and TA ranged between $23.75 \mathrm{meq} / \mathrm{kg}$ and $44.94 \mathrm{meq} / \mathrm{kg}$. White \& Doner (1980) reported FA values of between 30.29 and $66.02 \mathrm{meq} / \mathrm{kg}$ for honeydew honey samples. Bacandritsos (2004) reported a TA value of $36.1 \mathrm{meq} / \mathrm{kg}$ for pine honey. Our results were found to be consistent with these results. 
Based on Pillai's trace $(\mathrm{V}=2.982, \mathrm{~F}=2.704, \mathrm{p}=0.000<0.05)$ and Wilk's Lambda $(\Lambda=0.000, F=5.714, \mathrm{p}=0.000<0.05)$ statistics, MANOVA revealed that there was a significant multivariate effect of geographical origin on the combination of 13 predictors. However, according to separate univariate ANOVAs, only six of them (FA, LA, LA/FA, pH, EC, and lidocaine) were significant $(\mathrm{p}<0.05)$ for the classification of honey samples. Therefore, two different discriminant analyses were performed. The first discriminant analysis was conducted using all 13 predictors (Figure 2a), and the second using only the six significant predictors from ANOVA (Figure 2b).

By using all 13 predictors, LDA revealed two statistically significant discriminant functions:

First function: Wilk's Lambda $=0.000, \chi 2=136.412, \mathrm{df}=52$, $\mathrm{p}=0.000<0.05$

Second function: Wilk's Lambda $=0.009, \chi 2=75.988, \mathrm{df}=36$, $\mathrm{p}=0.000<0.05$

The first discriminant function accounted for $61.0 \%$ of the total variance while the second accounted for $35.8 \%$. As shown in Fig. 1a, all honey samples were correctly classified

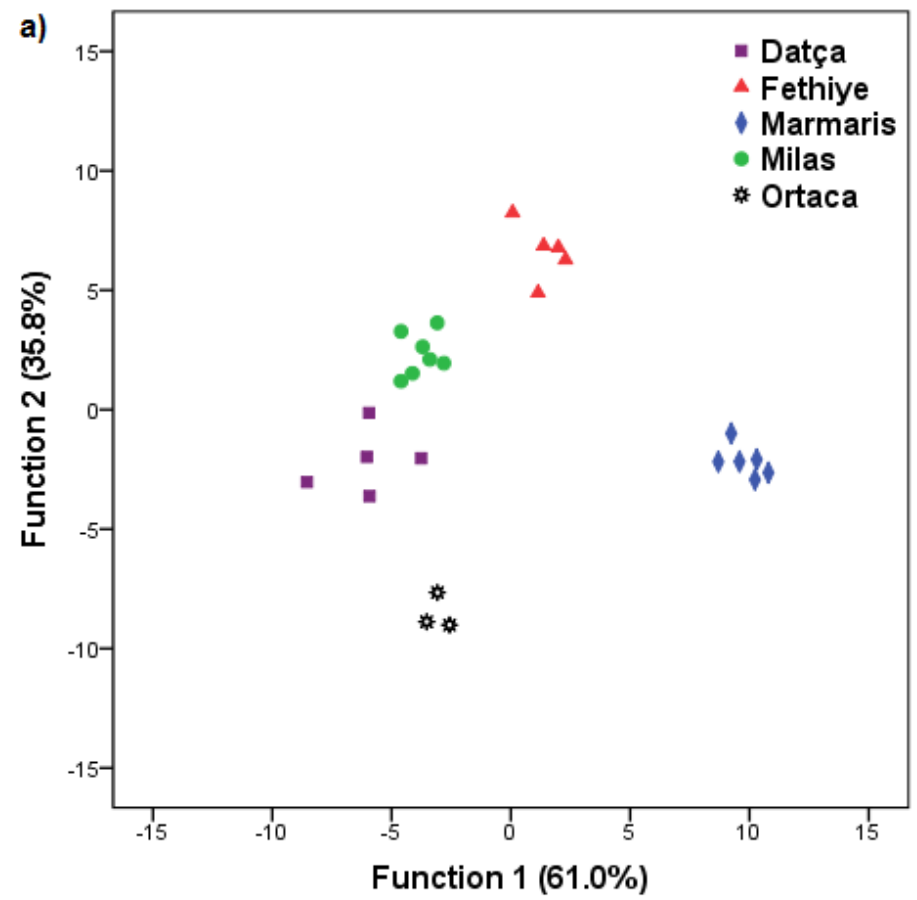

according to their geographical origin. Overall, $100 \%$ of original and $76.9 \%$ of cross-validated grouped cases were correctly classified.

By using the six significant predictors from ANOVA, LDA revealed two statistically significant discriminant functions: Wilk's Lambda $=0.019, \chi 2=77.727, \mathrm{df}=24, \mathrm{p}=0.000<0.05$

Second function: Wilk's Lambda $=0.141, \chi 2=38.146, \mathrm{df}=15$, $\mathrm{p}=0.001<0.05$

The first discriminant function accounted for $62.9 \%$ of the total variance while the second accounted for $31.9 \%$. Based on FA, LA, LA/FA, pH, EC, and lidocaine, honey samples from Milas and Ortaca were clearly distinguished from the other groups in which the correct classification rates for Marmaris, Datça, and Fethiye were $83.3 \%, 80 \%$, and $60.0 \%$, respectively. Overall, $84.6 \%$ of original and $69.2 \%$ of crossvalidated grouped cases were correctly classified.

The results of two discriminant analyses demonstrated that the use of non-significant predictors greatly increased the discrimination rate, and significant multivariate predictors could be as important as significant univariate predictors for sample discrimination.

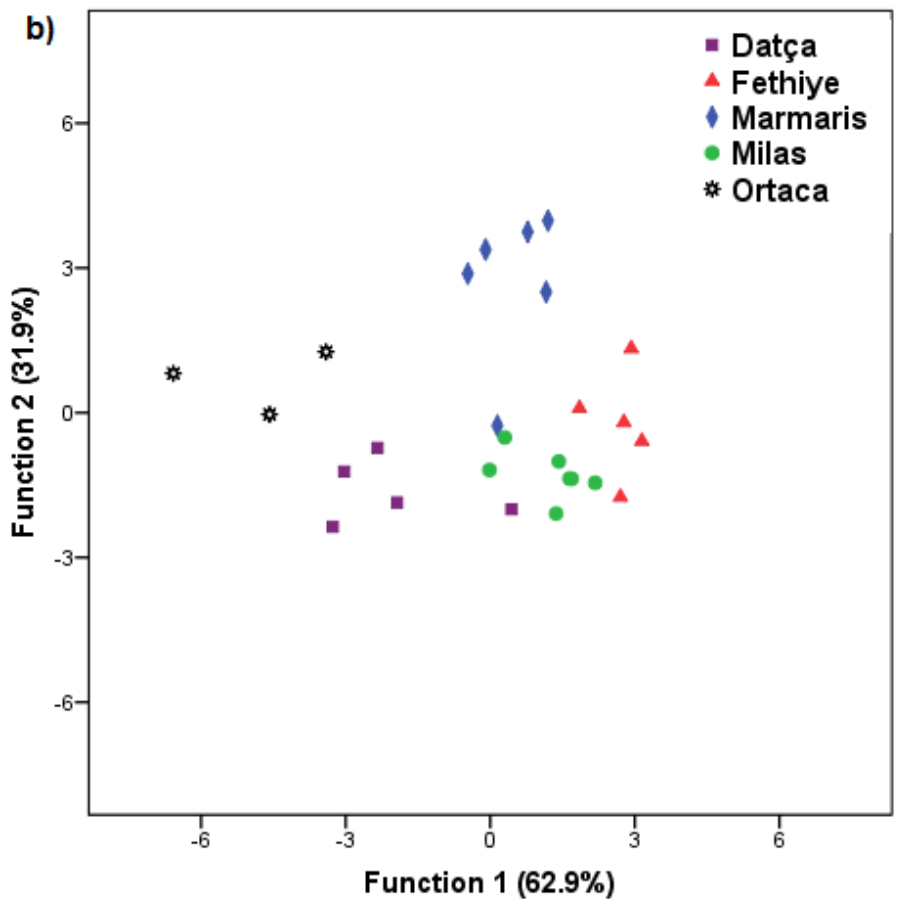

Figure 2. Discriminant functions scatter plot based on a) 13 parameters b) 6 ANOVA significant parameters 


\section{Conclusion}

This study showed for the first time a comprehensive analysis of Turkish pine honey. All honey samples were correctly classified according to their geographical origin based on microscopic properties, physicochemical properties, and volatile contents. The findings of this study are important for the characterization and authenticity of Turkish pine honey. In addition, these results can support the comparison and standardization of honeydew honey varieties in the world.

\section{Conflict of Interest}

The authors declare that there are no conflicts of interest.

\section{Acknowledgements}

We would like to thank The Scientific and Technological Research Council of Turkey (TÜBİTAK) for financial support, and the Muğla Beekeepers Association (MAYBİR) and local people who helped us during our fieldwork.

\section{References}

Bacandritsos, N. (2004). Establishment and honeydew honey production of Marchalina hellenica (Coccoidea Margarodidae) on fir tree (Abies cephalonica). Bulletin of Insectology, 57(2), 127-130.

Bogdanov, S. (1999). Honey quality, methods of analysis and international regulatory standards: Review of the work of the International Honey Commission. Mitteilungen aus Lebensmitteluntersuchung und Hygiene, 90(1), 108125.

Bogdanov, S. (2002). Harmonised Methods of International Honey Commission, International Honey Commission, pp. 1-62.

Codex Alimentarius Committee on Sugars. (2001). Codex standard 12. Revised Codex Standard for Honey, Standards and Standard Methods, 11, 1-7.

Council Directive /110/EC relating to honey, (2001). Official Journal of the European Communities, L 10/47-L $10 / 52$.

D'Arcy, B. (2007). High-Power Ultrasound to Control of Honey Crystallisation, Rural Industries Research and Development Corporation, Australia, 140 p.
Escuredo, O., Fernandez-Gonzalez, M., Carmen, S.M. (2012). Differentiation of blossom honey and honeydew honey from Northwest Spain. Agriculture, 2(1), 25-37.

Escuredo, O., Miguez, M., Fernández-González, M., Seijo, M.C. (2013). Nutritional value and antioxidant activity of honeys produced in a European Atlantic area. Food Chemistry, 138(2-3), 851-856.

FAOSTAT (2014). Food and Agriculture Organization of the United Nations FAO Statistics Division, Viale delle Terme di Caracalla 00153 Rome, Italy.

Karabagias, I.K., Badeka, A., Kontakos, S., Karabournioti, S., Kontominas, M.G. (2014). Characterisation and classification of Greek pine honeys according to their geographical origin based on volatiles, physicochemical parameters and chemometrics. Food Chemistry, $146,548-557$.

Krell, R. (1996). Value-Added Products from Beekeeping, Fao Agricultural Services Bulletin No. 124, Chapter 3, Pollen. Retrieved from http://www.fao.org/documents (accessed 12.2017).

Leshkov, Y.R., Juben, N.C., James, A.D. (2006). Phase modifiers promote efficient production of hydroxymethylfurfural from fructose. Science, 312(5782), 1933-1937.

Louveaux, J., Maurizio, A., Vorwohl, G. (1978). International Commission for Bee Botany of IUBS, methods of melissopalynology. Bee World, 59(4), 139-157.

MAYBIR (2015). Muğla İli Ar1 Yetiştiricileri Birliği. Retrieved from http://www.maybir.org.tr/ (accessed 12.2017).

Moreira, R.F.A., Maria, C.A.B., Pietroluongo, M., Trugo, L.C. (2010). Chemical changes in the volatile fractions of Brazilian honeys during storage under tropical conditions. Food Chemistry, 121(3), 697-704.

Nicholls, J., Miraglio, A.M. (2003). Honey and healthy diets. Cereal Foods World, 48(3), 116-119.

Özkök, A., Çıngı, H. (2010). Two different methods used in distinguishing pine honey from floral honey. Mellifera, 10(20), 14-23. 
Özkök, A., Sorkun, K., Salih, B. (2016). The Microscopic and GC-MS Analysis of Turkish Honeydew (Pine) Honey. Hacettepe Journal of Biology and Chemistry, 44(4), 375-383.

Santas, L.A. (1979). Marchalina Hellenica an Important Insect for Apiculture of Greece, the XXVII ${ }^{\text {th }}$ International Congress of Apicultural of Apimondia, Athens, pp 419-422.

Sanz, M.L., Gonzalez, M., Lorenzo, C., Sanz, J., MartinezCastro, I. (2005). A contribution to the differentiation between nectar honey and honeydew honey. Food Chemistry, 91(2), 313-317.

Silva, P.M., Gauche, C., Gonzaga, L.V., Costa, A.C.O., Fett, R. (2016). Honey: Chemical composition, stability and authenticity. Food Chemistry, 196, 309-323.

Simeonov, S.P., Coelho, J.A.S., Carlos, A.M. (2016). Synthesis of 5-(hydroxymethyl) furfural (HMF). Organic Synthesis, 93(1) 29-36.

Soria, A.C., Gonzalez, M., Lorenzo, C., Martinez-Castro, I., Sanz, J. (2004). Characterization of artisanal honeys from Madrid (Central Spain) on the basis of their melissopalynological, physicochemical and volatile composition data. Food Chemistry, 85(1), 121-130.

Sorkun, K. (2008). Türkiye' nin Nektarlı Bitkileri, Polenleri ve Ballar1 (Nectar Plants, Honeys and Pollens of Turkey), Palme Publishing, p. 341, ISBN 978-9944-34167-7.

Şahin, A. (2000). Marmaris-Muğla Yöresinde Üretilen Çam Ballarının Mikroskobik Analizi ve Organoleptik Özelliklerinin Saptanması (Microscopic Analysis and Determination of Organoleptic Properties of Pine Honeys Which are Produced in Marmaris-Muğla Region), Master Thesis, Hacettepe University, Ankara, 2000.

White, J.W., Doner, L.W. (1980). Beekeeping in The United States Agriculture Handbook Number 335. Retrieved from http://beesource.com/resources/usda/honeycomposition-and-properties/ (accessed 12.2017).

White, J.W. (1975). Physical Characteristics of Honey. In E. Crane (Ed.), Honey, a comprehensive survey (pp. 207239). London, UK: Hienemann. 